\title{
Dynamics of suspended sediment load in the Morava River (Serbia) in the period 1967-2007
}

\author{
Sanja MANOJLOVIĆ ${ }^{*}$, Predrag MANOJLOVIĆ ${ }^{1}$, Mrdjan DJOKIĆ \\ ${ }^{1}$ Faculty of Geography, University of Belgrade, Belgrade, Serbia \\ ${ }^{2}$ Faculty of Science and Mathematics, Department of Geography, University of Niš, Niš, Serbia \\ Received 22 June 2016; Revised 9 July 2016; Accepted 26 September 2016 \\ *Correspondence to: Sanja MANOJLOVIĆ, e-mail: sanjam@gef.bg.ac.rs
}

\section{ABSTRACT}

The study is concerned with determination of the trend of water discharge, suspended sediment concentration and sediment load in the most downstream profile of the Velika Morava River in the period 1967-2007. The gradual trend test (Mann-Kendall test - MK test) and abrupt change test (Pettitt test) have been employed on annual, seasonal and monthly water discharge, suspended sediment concentration and suspended sediment load for the given time series. Both the Mann-Kendall and Pettitt tests indicate that water discharge showed no significant annual trend or abrupt shift. However, annual suspended sediment concentration and sediment load showed significant decreasing trends $(\alpha=0.001)$. The average decrease of suspended sediment load transport amounted to $3.15 \mathrm{t} / \mathrm{km}^{2} / \mathrm{yr}$. The Pettitt test results showed that the change-point year was detected in 1982 . The average specific sediment load amounted to $134.6 \mathrm{t} / \mathrm{km}^{2} / \mathrm{yr}$ before the transition year, and $36.5 \mathrm{t} / \mathrm{km} / \mathrm{yr}$ after the transition year, i.e., it was reduced by $73 \%$. In the intra-annual distribution, the MK test results indicate that the most pronounced decreasing trend $(\alpha=0.001)$ of the sediment load is during summer and winter. Strong seasonal and monthly variability in sediment load was found. Sediment was strongly transported during spring months, in the period of frequent flood events. Almost $50 \%$ of the annual sediment is transported during March, April and May. Analysis of the discharge and suspended sediment concentration relationship revealed the existence of hysteresis loop in the shape of figure eight. The results of this study confirm the complex and heterogeneous nature of sediment response in the Velika Morava River.

\section{KEYWORDS}

trend of water discharge, suspended sediment concentration, suspended load, interannual and intraannual variability, Velika Morava, Serbia 


\section{Introduction}

Erosive sediment production in river basins and sediment load in watercourses are essential components of global natural process. Establishing a quantitative description of riverine fluxes is one of the main goals of contemporary hydrology and geomorphology (Cohen et al., 2014). Factors that control the intensity of suspended sediment load in the riverbeds are different. Precipitation, runoff and lithological composition stand out of natural factors (Chakrapani and Subramanian, 1990; Chakrapani, 2005). On the other hand, studies around the world have shown the evident anthropogenic impact based on different human activities. Walling and Fang (2003) point out the impact of reservoir construction, land clearance and land use change, soil and water conservation and sediment control programmes on changes in suspended sediment in rivers. Some studies have shown that the impact of humans in some cases is greater than the evident climate change, as is the case of impact of the mines (Bobrovitskaya et al., 2003). Hook (2006) attributes changes in the intensity of soil erosion and fluvial systems to the impact of deforestation, different forms of ploughing, as well as demographic changes, urbanization and the impact of construction of large dams. The results obtained by Walling and Fang (2003) and Walling (2006) indicated that almost half (70) of the rivers showed no evidence of a statistically significant trend in the sediment loads, but as a remainder, most (68 rivers) of them showed evidence of a significant decrease. Only 7 rivers were characterized by a significant increase in the sediment loads. They also point out that the observed trend of a decrease in the suspended sediment load is largely attributed to the influence of anthropogenic factors. Researches of other studies have shown similar results.

Due to the consequences on the condition and quality of the environment, the study of the dynamics and suspended sediment load has great environmental and water management impact. The ecological aspect is primarily viewed in the quality of water in river flows and chemical pollution of watercourses, as it is known that suspended sediment is the main transporter of chemical pollutants. The study of the dynamics and sediment load from the water management aspect involves consideration of its impact on different water management facilities such as regulated riverbeds, irrigation channels, water intakes, etc., but primarily emphasizes consideration of problems regarding the reservoir siltation.

In this context, the study of suspended sediment trends on the Velika Morava River is of great importance, bearing in mind the fact that the sediment transported by this river has a direct impact on the accumulation zone of the Hydroelectric Power Station "Djerdap I" (the Iron Gate I Hydroelectric Power Station). The study of the sediment load trend on the Danube downstream from the reservoir showed that the construction of the dam led to its reduction by $70 \%$ (Walling, 2006). It is estimated that in the total amount of sediment entering the reservoir sector downstream of the Velika Morava River, the sediment which entered by the Danube participates by $41 \%, 26 \%$ by the Tisa River, $21 \%$ by the Sava River, and $12 \%$ by the Velika Morava River (Babić-Mladenović, 2007) and that the reservoir retains about $80 \%$ of the total sediment load entered by the Danube, so that the reservoir of the "Djerdap I" is probably the largest reservoir storage of sediments in Europe (Petković et al., 1999). The objective of the research in this study is to statistically detect trends and change-points (transition year) in annual discharge and suspended sediment load and determine changes in sediment transport in the period before and after the observed transitional year. Also, the objective of this paper is to statistically detect trends in seasonal and monthly discharge and suspended sediment load and determine the type of hysteresis loop defined through the relationship of discharge and suspended sediment concentration.

\section{Physical-geographical characteristics}

The Velika Morava River Basin covers an area of $37,561 \mathrm{~km}^{2}$, accounting for $42.5 \%$ of the territory of the Republic of Serbia. The basin is of three hydrographic parts: direct basin of the Velika Morava River $\left(6,242 \mathrm{~km}^{2}\right)$, the Južna Morava River Basin $\left(15,469 \mathrm{~km}^{2}\right)$ and the Zapadna Morava River Basin $\left(15,850 \mathrm{~km}^{2}\right)$. 


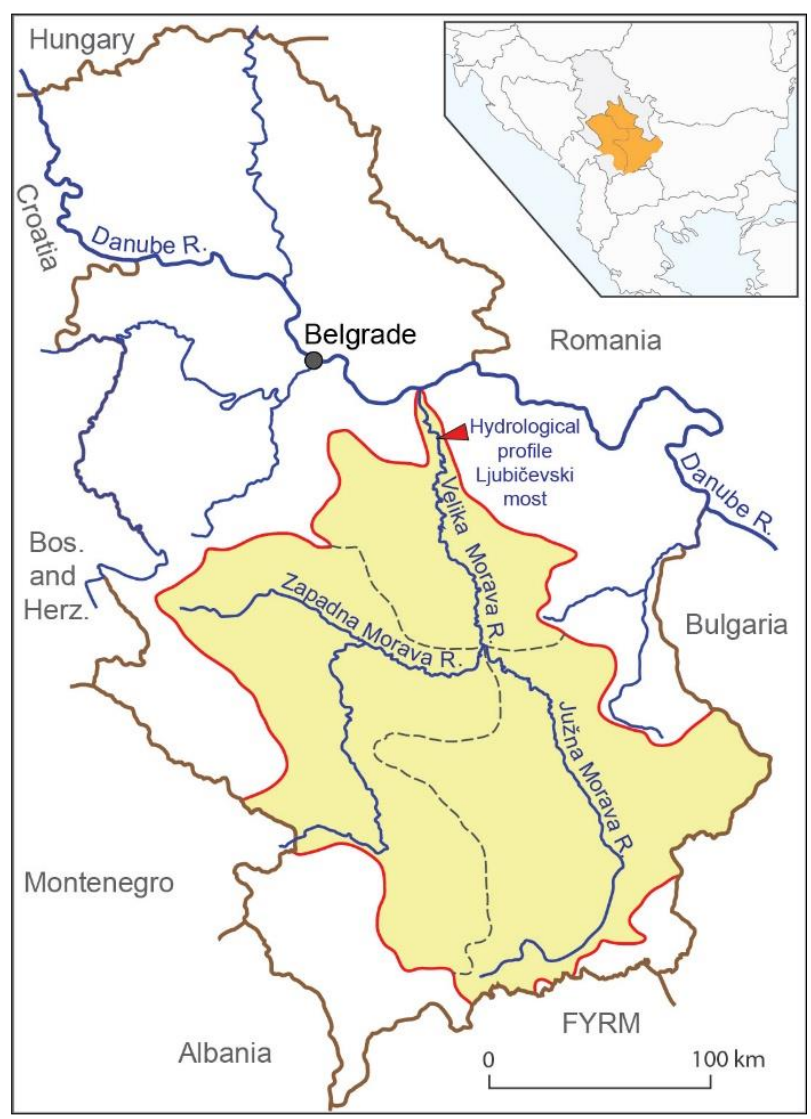

Figure 1 Geographical location of the Morava River in Serbia and on the Balkan Peninsula

Average altitude of the basin is $622 \mathrm{~m}$, the lowest point is $67 \mathrm{~m}$ at the confluence of the Velika Morava River and the Danube, and the highest point is on the mountain Hajla at 2,500 m above sea level. In hypsometric terms, the largest part of the basin area (77\%) is between $200-1,000 \mathrm{~m}$ above sea level (Ocokoljić, 1987).

Dynamics of river discharge and suspended sediment load greatly depend on the basin geological substratum. The Velika Morava River Basin is characterized by a very diverse geological structure. The Zapadna and Južna Morava River Basins, constituting $83.38 \%$ of the Velika Morava River Basin, are largely covered by rocks subjected to water erosion and of great quantity of suspended sediment load - flych 23.88\%, Holocene alluvium $17.28 \%$ (mostly fine particles of silt and clay and larger particles of sand and gravel), quartz sandstones $9.87 \%$, Neogene lake sediments $4.14 \%$ (mostly sand and gravel). Direct basin of the Velika
Morava River, covering $16.62 \%$ of the Velika Morava River Basin, is mostly covered by Holocene alluvium and Neogene lake sediments.

Integral vulnerability map of the natural hazards in the territory of Serbia shows that the valley of the Velika Morava River near Stalać to the confluence into the Danube, as well as the valleys of its constituents, the Južna Morava River and the Zapadna Morava River, belong to potential flood zones (Dragicevic et al., 2011; Ristić et al., 2012). Analysis of floods in the Morava River Basin shows that they usually occur in late spring or early summer during periods of frequent cyclones. They mostly belong to floods caused by rainfall and snow-melt and floods caused by the coincidence of high waters, and torrent floods are common in the Južna Morava River Basin (Gavrilović et al., 2012). In the last hundred years even 479 torrential flood events were registered in the basin (Petrovic et al., 2014). Water regime of the Velika Morava River is determined by the regime of its constituents. Thus, the Južna Morava River participates with $43.2 \%$ and the Zapadna Morava River with 45.7\%, while the direct part of the Velika Morava River Basin with only $10.9 \%$ of the total runoff (Gavrilović, 2006). The Velika Morava River is the river with the highest discharge fluctuations, the annual coefficient of variation is of 0.30 and is caused by continental regime of precipitation, high evaporation and pluvial-nival regime of its tributaries (Ocokoljić, 1994). The largest part of the basin area is of 600 $800 \mathrm{~mm}$ of precipitation on the average, while the highest mountainous parts even up to $1,100 \mathrm{~mm}$ (Ducić and Radovanović, 2005).

\section{Methodology}

In this study we used the measurements from the hydrological station Ljubičevski most (official data of the Republic Hydrometeorological Service of Serbia) in the period 1967-2007. The station is located on the Velika Morava River, at a distance of $21.75 \mathrm{~km}$ from its confluence with the Danube. The basin area of the Velika Morava River is $37,320 \mathrm{~km}^{2}$ upstream of the station, while the length of river upstream is $471.25 \mathrm{~km}$, together with the Zapadna Morava River 
as the source arm. Descriptive statistics for discharge $(Q)$, suspended sediment concentration (SSC) and sediment load (QS) are given in Table 1. There are indications that these models cannot be replicated in each year, and at all discharge conditions, but it will certainly be a good basis for further analysis leading to the universal solution.

Two non-parametric tests were used, which meant that their application required no assumption about the distribution of water discharge ( $Q$ ), suspended sediment concentration (SSC) and suspended sediment load ( $Q s$ ) data from the given time series (1967-2007), on annual, seasonal and monthly basis. In other words, the tests are distribution-free and it is not required to assume a special form of the data distribution, including potentially missing data, which is very common for hydrological data. The Mann-Kendall test is widely used to investigate if the trend exists in a given time series.

Table 1 Descriptive statistics for discharge (Q), suspended sediment concentration (SSC) and sediment load (Qs)

\begin{tabular}{lcrrrrr}
\hline & Unit & Mean & Minimum & Maximum & Standard deviation & Coefficient of variation \\
\hline Discharge (Q) & $\mathrm{m}^{3} / \mathrm{s}$ & 220.3 & 101.1 & 348.9 & 61.5 & 0.28 \\
$\begin{array}{l}\text { Suspended sediment } \\
\text { concentration (SSC) }\end{array}$ & $\mathrm{g} / \mathrm{l}$ & 0.2173 & 0.0466 & 0.6909 & 0.1827 & 0.84 \\
Sediment load (Qs) & $\mathrm{t} / \mathrm{yr}$ & 2568998.6 & 170197.4 & 10015588.2 & 2317405.4 & 90.2 \\
\hline
\end{tabular}

It is often applied for trend determination of climatic indicators and it is recommended by the World Meteorological Organization (Salarijazi et al., 2012; Mitchell et al., 1996), as well as, for evaluation of hydrological data (Yue et al., 2002; Yue et al., 2003; Yue et al., 2004; Salarijazi et al., 2012; Karmeshu, 2012).The purpose of this test is to statistically estimate whether an upward or downward trend appears in data series in the scope of time. The obtained trend may or may not be linear.

The initial assumption of the Mann-Kendall test is that the trend does not exist $\left(\mathrm{H}_{0}\right)$, or otherwise, the observations are not serially correlated during time. In order to reject the initial assumption (accept the alternative hypothesis $-\mathrm{H}_{\mathrm{a}}$ ), it is necessary that the test result is lower than the significance level $-\alpha$ (common value is 0.001). Lower value of the significance level $\alpha$ decreases the possibility that the (the trend does not exist) is wrongfully rejected. The value of the Sen's slope (b) shows the trend magnitude, either upward or downward.

As the Mann-Kendall test, the Pettitt test (Pettitt, 1979) was carried out to determine whether there was the trend in value changes of water discharge, suspended sediment concentration, and suspended sediment load. The Pettitt test also shows if there is a transition point - year (changepoint) when it comes to a change in trend, and if it exists, which transition point is in question.

The existence of the transition year (changepoint) does not mean that the values changed in that particular year, but that there were two periods when the measured values extremely differed. In other words, the change did not happen in one year, but the change-point separated the two different periods. The Pettitt test is widely used to detect changes in the observed hydrological data series, including suspended sediment load (Gao et al., 2011; Gao et al., 2012; Meysam et al., 2012).

Similarly, as for the Mann-Kendall test, the initial assumption of the Pettitt test is that the trend does not exist $\left(\mathrm{H}_{0}\right)$, i.e., that the data are homogeneous throughout the whole period of observation, and that there is no transition year when the values change in positive or negative terms. The alternative hypothesis $\left(\mathrm{H}_{\mathrm{a}}\right)$ is accepted in the case when the test result ( $p$ ) is lower than the significance level $-\alpha$. The significance level can be changed with the common values of 0.05 or 0.001 . The higher $p$ value, the higher possibility to wrongfully reject the initial assumption, i.e., the lesser probability for the trend and the transition point to exist. 


\section{Results and discussion}

\subsection{Interannual variability of suspended sediment load}

The average perennial discharge on the hydrological profile Ljubičevski most on the Velika Morava River in the period $1960-2007$ is $220.3 \mathrm{~m}^{3} / \mathrm{s}$, which gives a specific runoff value of $6.2 \mathrm{l} / \mathrm{s} / \mathrm{km}^{2}$. The minimal average annual discharge value amounted to $101.1 \mathrm{~m}^{3} / \mathrm{s}$, and the maximal average annual value was of $348.9 \mathrm{~m}^{3} / \mathrm{s}$, so that the specific runoff amounted to $2.85 \mathrm{l} / \mathrm{s} / \mathrm{km}^{2}$, or $9.83 \mathrm{l} / \mathrm{s} / \mathrm{km}^{2}$. The average suspended sediment concentration is of $0.2173 \mathrm{~g} / \mathrm{l}$, and ranges from 0.0466 to $0.6909 \mathrm{~g} / \mathrm{l}$.
The average perennial suspended sediment transport is of $2.57 \times 106 \mathrm{t}\left(72.4 \mathrm{t} / \mathrm{km}^{2} / \mathrm{yr}\right)$, and ranged from $0.17 \times 106 \mathrm{t}\left(4.8 \mathrm{t} / \mathrm{km}^{2} / \mathrm{yr}\right)$ to $10.02 \times 106 \mathrm{t}$ (282.2 t $/ \mathrm{km}^{2} / \mathrm{yr}$ ). Extremum ratio for $Q, S S C$ and $Q S$ is 1:3.4, 1:14.8 and 1:58.8 respectively. The results of the Mann-Kendall (MK) test for the gradual trends of discharge $(Q)$, suspended sediment concentration (SSC) and sediment load (QS) are given in Table 2. There has been a gradual trend of decrease in $Q$, SSC and Qs. However, there are no significant trends detected for water discharge series, but the trends for SSC and Qs show high significance $(\alpha=0.001)$. The Sen's slope curve shows that the average decrease of $Q$ is of $0.82 \mathrm{~m}^{3} / \mathrm{s} / \mathrm{yr}$, respectively $0.021 \mathrm{l} / \mathrm{s} / \mathrm{km}^{2} / \mathrm{yr}$.

Table 2 Results of Mann-Kendall test for annual water discharge (Q), suspended sediment concentration (SSC) and suspended sediment load (Qs)

\begin{tabular}{cccccccccc}
\hline Time series & \multicolumn{3}{c}{$\boldsymbol{Q}\left(\mathbf{m}^{\mathbf{3}} \mathbf{/ s}\right)$} & \multicolumn{3}{c}{$\boldsymbol{S S C}(\mathbf{g} / \mathbf{l})$} & \multicolumn{3}{c}{$\boldsymbol{Q s}(\mathbf{t} / \mathbf{y r})$} \\
\cline { 2 - 9 } & $\mathrm{b}^{*}$ & $\mathrm{Z}$ & $\alpha^{* *}$ & $\mathrm{~B}$ & $\mathrm{Z}$ & $\alpha$ & $\mathrm{b}$ & $\mathrm{Z}$ & $\boldsymbol{\alpha}$ \\
\hline Annual & -0.82 & -0.75 & 0 & -0.0096 & -4.14 & 0.001 & -111094.5 & -4.21 & 0.001 \\
\hline \multicolumn{4}{c}{${ }^{*}$ Sen's slope estimate (b). ${ }^{*}$ Significance level $(\alpha)$} &
\end{tabular}

Table 3 Results of Pettitt test for discharge ( $Q$ ), suspended sediment concentration (SSC) and suspended sediment load (Qs) (significance level $\alpha=0,05$ )

\begin{tabular}{|c|c|c|c|c|c|c|c|}
\hline Damamoto & Pettitt test & & & & & & \\
\hline Parameter & K & $p$ & Shift & $T^{*}$ & Pre - T & Post - T & average \\
\hline$Q\left(\mathrm{~m}^{3} / \mathrm{s}\right)$ & 128 & 0.370 & No change & - & - & - & 220.3 \\
\hline $\operatorname{SSC}(\mathrm{g} / \mathrm{l})$ & 346 & 0.0001 & Downward & 1982 & 0.4010 & 0.1113 & 0.2173 \\
\hline$Q_{s}(t / y r)$ & 350 & 0.0001 & Downward & 1982 & 4778885.9 & 1294063.6 & 2568998.6 \\
\hline
\end{tabular}
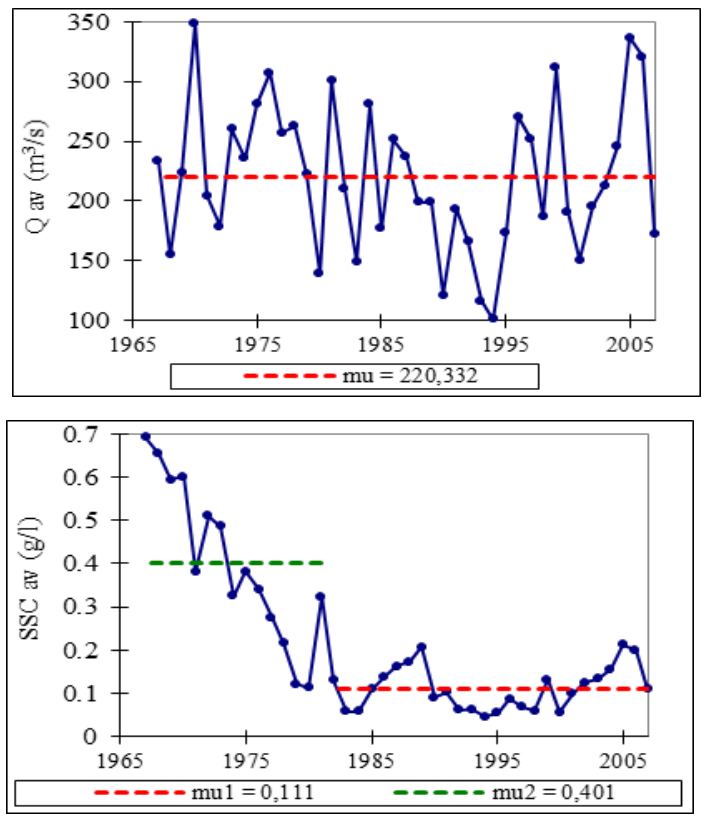

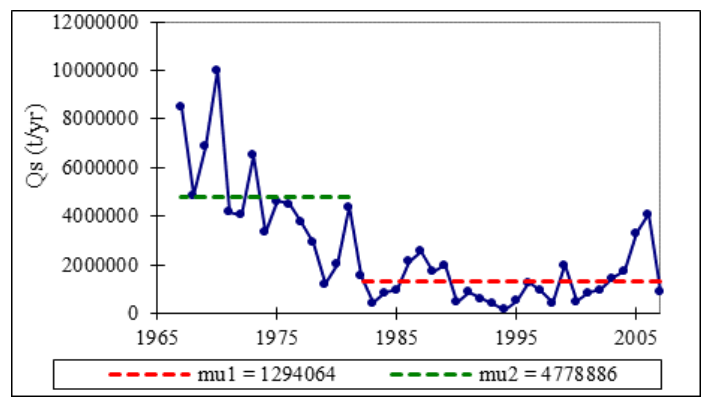

Figure 2 Results of Pettitt test for discharge $(Q)$, suspended sediment concentration (SSC) and suspended sediment load (QS) for the time series 1967-2007 
The average decrease of SSC is of $0.0096 \mathrm{~g} / \mathrm{l} / \mathrm{yr}$, and the average decrease of Qs is of 111,094.5 t/yr, i.e., the average specific rate of decrease is of $3.13 \mathrm{t} / \mathrm{km}^{2} / \mathrm{yr}$. The results of the Pettitt test for abrupt changes in $Q, S S C$ and $Q$ s are given in Table 3 and Fig. 2. At the level of significance of 0.05 , there are no abrupt changes in discharge for a given period of time. On the other hand, the SSC and QS have abrupt significant changes downwards. The change point (transition year) in both cases is theyear of 1982.The average specific sediment load before the transition year (change-point) amounted to $134.6 \mathrm{t} / \mathrm{km}^{2} / \mathrm{yr}$ and after the transition year it was $36.5 \mathrm{t} / \mathrm{km}^{2} / \mathrm{yr}$, or it was decreased by $73 \%$. Also, the average values of the SSC decreased by $72 \%$ after the transition year.

Since the time series of $Q s$ are divided into two segments based on their change point, the gradual trends of $Q$ s before and after the transition year can be further investigated. The results of the MK for $Q$, SSC and Qs before and after the transition year are displayed in Table 4. Before and after the transition year, SSC and Qs show opposite trends. Therefore, although the period before the transitional year, the discharge recorded a slight upward trend, SSC and
Qs had a distinctive decreasing trend, significant at the level of 0.0001 , i.e., 0.001 respectively. The average decrease of suspended sediment in the period 1967-1982 amounted to $370,176.5 \mathrm{t} / \mathrm{yr}$, i.e., $10.4 \mathrm{t} / \mathrm{km}^{2} / \mathrm{yr}$. On the other hand, $Q$, SSC and Qs after the transition year show a slight upward trend, that is not significant.

The opposite trends of Qs before and after change points suggest that there were different controlling factors of sediment load in different periods. Gao et al., (2011) suggests that in stable climatic-hydrologic conditions, the trend of decrease in sediment can be explained solely by anthropogenic impacts. Taking into account the fact that the measuring station on the Velika Morava River in the period before the transitional year had a growing trend in the discharge and declining in the concentration and sediment transport, a strong reduction of suspended sediment could be attributed to anthropogenic impacts. On the other hand, the slightly increasing trend observed in all three parameters $(Q, S S C, Q S)$ in the period after the transition year may be due to the influence of precipitation.

Table 4 Results of Mann-Kendall test for annual water discharge (Q), suspended sediment concentration (SSC) and suspended sediment load (Qs) before and after significant points in the year of 1982.

\begin{tabular}{|c|c|c|c|c|c|c|c|c|c|}
\hline \multirow{2}{*}{ Time series } & $Q\left(\mathrm{~m}^{3} / \mathrm{s}\right)$ & & & $S S C(g / l)$ & & & $Q_{s}(t / y r)$ & & \\
\hline & b & Z & $\alpha$ & b & Z & $\alpha$ & b & Z & $\alpha$ \\
\hline Pre - T & 4.09 & 0.69 & 0 & -0.0421 & -4.16 & $* * *$ & -370176.5 & -2.79 & ** \\
\hline Post - T & 1.82 & 0.79 & 0 & 0.0013 & 1.06 & 0 & 12448.8 & 0.88 & 0 \\
\hline
\end{tabular}

T- transition year, $\mathrm{b}$ - Sen · s slope estimate, $\alpha$ - significance level: $0=$ no significance; $+\alpha=0.1 ;{ }^{*} \alpha=0.05 ;{ }^{* \star} \alpha=0.01 ;{ }^{* \star *} \alpha=0.001$

Specifically, the analysis of precipitation of the measuring stations in the basin shows an increasing trend after 1980 (Gocić M., and Trajković S., 2013). Climate research studies throughout Serbia (Unkašević M., Tošić I., 2014; Kutiel H., Luković J., Burić D., 2015) showed that wet years dominated in climate classification in the first decade of the XXI century.

\subsection{Intraannual variability of suspended sediment load}

In the intraanual distribution, the highest sediment load is realized in spring: in March (18\%), in April
(17.9\%), in May (11.7\%), accounting for almost half of the annual summary sediment load in total. The smallest sediment load is linked to autumn and the end of the year. So, in September it accounted for $2.1 \%, 2.4 \%$ in August, 2.8\% in October, $2.9 \%$ in November in the total annual distribution (Mustafić et al., 2014).

The results of the MK test for seasonal and monthly changes in $Q, S S C$ and $Q$ s are given in Table 5 and Table 6. Changes in discharge on seasonal and monthly basis show different trends. Period from February to September (with the exception of April) shows decreasing trend in 
discharge, while a mild increasing trend is related to the period from October to January. However, the observed changes are not statistically significant. Seasonal and monthly changes in the suspended sediment concentration are characterized by a strong downward trend. The level of significance is of 0.001 for winter, spring and summer, and 0.01 for autumn. The results of the MK test show the strongest downward trend for May, June, July, August and September and two winter months of January and February.

Changes in the seasonal distribution of suspended sediment load show a downward trend. The most obvious decreasing trend is evident during summer and winter at the level of significance of 0.001 , and the lowest in autumn. Changes on the monthly level show negative trends without exception during all 12 months. However, these changes in October and November have no statistical significance, and in April they are significant at the level of 0.1 . The most prominent significant changes of suspended sediment are in July and August at the level of 0.001, which shows a strong downward trend ( $Z$ values of the MK test amount to $-3.85,-3.45$ respectively). Also, two more months, June and September, recorded a pronounced decreasing trend of suspended sediment at the level of significance of 0.01 . Monthly suspended sediment load displayed in Figure 3 shows the average decade values. These values clearly reflect the dynamics of suspended sediment load in the seasonal pattern. Intraanual suspended sediment load shows significant changes. It can be clearly seen that the peak of monthly suspended sediment load in recent decades almost always happens in March and April, which is in accordance with intraanual discharge distribution.

Table 5 Results of Mann-Kendall test for seasonal water discharge $(Q)$, suspended sediment concentration (SSC) and suspended sediment load (QS)

\begin{tabular}{|c|c|c|c|c|c|c|c|c|c|}
\hline \multirow[t]{2}{*}{ Seasons } & $\begin{array}{c}Q \\
\left(\mathrm{~m}^{3} / \mathrm{s}\right) \\
\end{array}$ & & & $\begin{array}{l}S S C \\
(\mathrm{~g} / \mathrm{l}) \\
\end{array}$ & & & $\begin{array}{c}Q_{s} \\
(t / y r)\end{array}$ & & \\
\hline & b & Z & $\alpha$ & $\mathrm{b}$ & Z & $\alpha$ & b & Z & $\alpha$ \\
\hline Winter & -0.14 & -0.01 & 0 & -0.0066 & -3.99 & $* * *$ & -18853.1 & -3.45 & $* * *$ \\
\hline Spring & -1.32 & -0.53 & 0 & -0.0089 & -3.63 & $* * *$ & -35881.8 & -3.02 & $* *$ \\
\hline Summer & -0.76 & -0.86 & 0 & -0.0109 & -4.57 & $* * *$ & -16636.4 & -4.05 & $* * *$ \\
\hline Autumn & 0.50 & 0.62 & 0 & -0.0032 & -2.86 & $\star *$ & -2330.1 & -1.94 & + \\
\hline
\end{tabular}

B - Sen's slope estimate, $\alpha$ - significance level: $0=$ no significance; $+\alpha=0.1 ;{ }^{*} \alpha=0.05 ;{ }^{* \star} \alpha=0.01 ;{ }^{* \star \star} \alpha=0.001$

Table 6 Results ofMann-Kendall test for monthly water discharge (Q), suspended sediment concentration (SSC) and suspended sediment load (QS)

\begin{tabular}{|c|c|c|c|c|c|c|c|c|c|c|c|c|c|}
\hline & & I & II & III & IV & V & VI & VII & VIII & IX & $\mathbf{X}$ & $\mathbf{X I}$ & XII \\
\hline \multirow{3}{*}{$\begin{array}{c}Q \\
\left(\mathrm{~m}^{3} / \mathrm{s}\right. \\
)\end{array}$} & $b$ & 0.17 & -1.29 & -1.06 & 0.74 & -1.45 & -0.91 & -1.68 & -0.27 & -0.32 & 0.39 & 0.75 & 0.35 \\
\hline & Z & 0.10 & -0.91 & -0.48 & 0.19 & -1.02 & -0.71 & -1.70 & -0.64 & -0.84 & 0.53 & 0.84 & 0.33 \\
\hline & $\alpha$ & 0 & 0 & 0 & 0 & 0 & 0 & + & 0 & 0 & 0 & 0 & 0 \\
\hline \multirow{5}{*}{$\begin{array}{c}S S C \\
(g / l)\end{array}$} & $b$ & - & - & -0.0099 & - & - & - & - & - & - & - & - & - \\
\hline & & 0.006 & 0.008 & & 0.006 & 0.008 & 0.010 & 0.009 & 0.005 & 0.003 & 0.002 & 0.002 & 0.003 \\
\hline & & 8 & 0 & & 2 & 0 & 9 & 4 & 1 & 7 & 0 & 0 & 5 \\
\hline & Z & -3.43 & -3.47 & -3.22 & -2.30 & -3.31 & -4.01 & -4.05 & -3.56 & -3.88 & -1.72 & -2.12 & -2.44 \\
\hline & $\alpha$ & $* * *$ & $* * *$ & ** & * & $\star \star \star *$ & $* * *$ & $\star * *$ & $\star \star *$ & $\star * *$ & + & * & * \\
\hline \multirow{5}{*}{$\underset{(t / y r)}{Q_{S}}$} & $b$ & - & - & - & - & - & - & - & - & -872.0 & -319.0 & -573.9 & - \\
\hline & & 5011. & 6575. & 12236. & 5553. & 5621. & 6393. & 4316. & 1403. & & & & 1775. \\
\hline & & 4 & 1 & 0 & 1 & 3 & 4 & 1 & 4 & & & & 8 \\
\hline & Z & -2.66 & -2.48 & -2.44 & -1.72 & -2.44 & -3.27 & -3.83 & -3.45 & -3.27 & -1.49 & -1.09 & -2.03 \\
\hline & $\alpha$ & ** & * & * & + & * & ** & $* * *$ & $* * *$ & ** & 0 & 0 & * \\
\hline
\end{tabular}



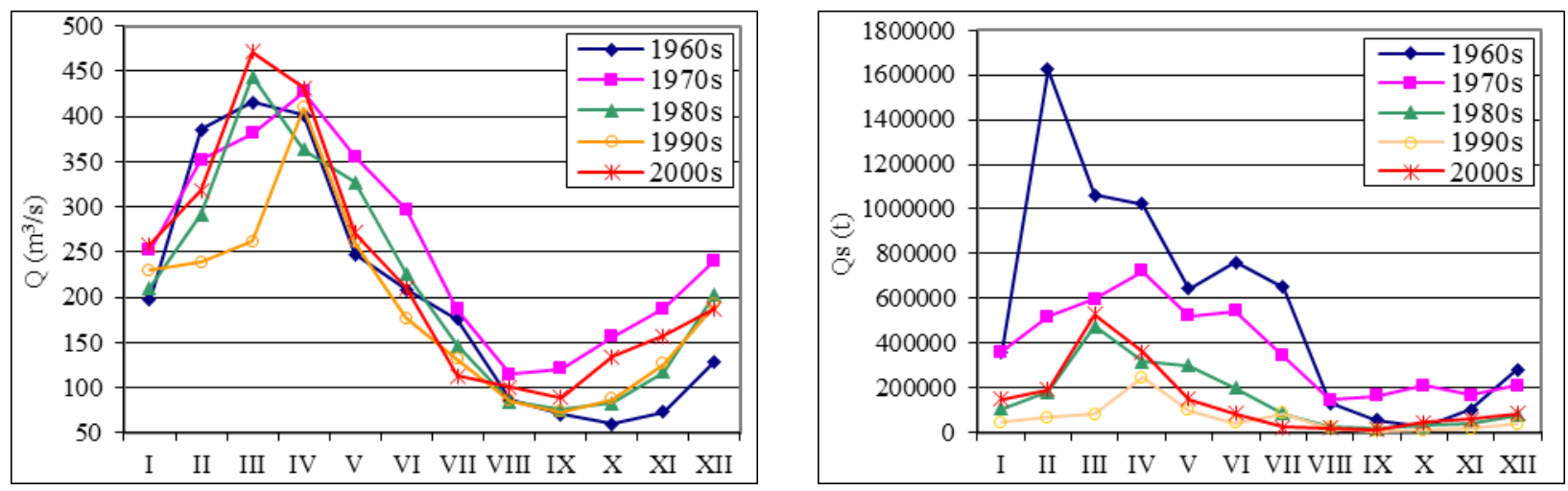

Figure 3 Monthly distribution of water discharge $Q\left(\mathrm{~m}^{3} / \mathrm{s}\right)$ and suspended sediment load $Q s$ (t/yr) in different decades.

It can be clearly seen that the peak of monthly suspended sediment load in recent decades almost always happens in March and April, which is in accordance with intraanual discharge distribution. The exception is the period of the late 1960s, when it was recorded in February. This distribution of the suspended sediment is generally consistent with the intraannual discharge distribution. Specifically on the rivers in the Velika Morava River Basin, most common periods of maximal discharge phenomena are from the end of spring, in April, May, to the first half of June and the end of winter from February and March (Ristić et al., 2012). However, although the peak of Qs always occurs in March or April, the differences between certain decades are very significant. The largest suspended sediment load during March and April we have in the period 1960s-1970s, which dramatically decreases during the 1990s, and shows slight upward trend after the 2000s. A change in the dynamics of suspended sediment is best illustrated by the fact that the ratio between the maximal monthly suspended sediment load in March in 1960s and 1990s is 1:13. That is, the suspended sediment load in the1990s is only $7.6 \%$ of the sediment load in the 1960 s.

In order to determine changes in the dynamics and suspended sediment load, we widely use the hysteresis curve. Sediment rating curve or hysteresis curve empirically describes the relationship between suspended sediment concentration (SSC) and discharge $(Q)$. In this study, three hysteresis loops are shown (Fig. 4). The first is for the entire observation period 1967-2007, the second for the period before the transition year T (1967-1981) and the third for theperiod after the transition year $T$ (1982-2007). Given the existence of 5 types of loops
(Williams, 1989), the shape of hysteresis loop is in the form of figure eight in all three cases. Hysteresis loop in the form of figure eight points to complex conditions. It contains the elements of the loop, which is clockwise, but alsothe elements of the loop of opposite direction. This type of loop can be understood as the seQuence of dominant conditions which alterate during the year (Seegeret al., 2004; Soler et al., 2008). In the first phase (January-May), which reflects the loop in a clockwise direction, the conditions of high surface runoff are dominant. Due to soil saturation with water (snowmelt in late winter and early spring and spring rains), its capacity to retain water is getting smaller, which implies more intense runoff. The peak of SSC (February and March) is before the occurrence of the maximal $Q$ (April), which points to the events of short duration. Land particles eroded in the basin can be easily transported during rainfall-runoff events and Quickly enter the watercourse (Fang et al., 2011). In the second phase (the period MayOctober), the loop shows the opposite character. Very high suspended sediment concentration occurs after the occurrence of the maximaldischarge. High intensity precipitation (June) is dominat, which shows that the source of sediments can be active in a wider area (Mustafić et al., 2013). After June, SSC has a sudden decreasing tendency and reaches its minimum in October. Since October, the orientation of the hysteresis loop changes again and takes the clockwise direction. Although both hysteresis loops done for the period before and after the transition year $T$ have the character and the shape of the figure eight, certain changes in the relationship between SSC and $Q$ were observed. Thus, for the maximal values of $Q$ (April), the values of SSC after 
the transition year were 2.7 times lower than in the period before the transition year. Also, in the period after T,the suspended sediment concentrations significantly decreased, especially during February and June. The MK test results point to this as well: the decrease trend of SSC is highly significant $(\alpha=0.001)$, and $Z$ values for February and June amount tohigh $-3.47,-4.01$ respectively. As a result of the current changes, now the largest value of SSC can be expected only in March and April, in contrast to the period before the transition year, when the other very pronounced peak of SSC was in June. The minimal value of SSC moved toward September. In this sense, two periods of the year are clearly demonstrated. The first period records an increase in the value of SSC with increasing $Q$ and lasts from November to March, which is two months longer than regarding the period before the transition year, when it lasted from October to February. The second period records the decrease in SSC and lasts from April to September when it reaches its minimum.

\section{Some aspects of human impact on decreasing trend of suspended sediment}

The abrupt decrease of suspended sediment load can be largely attributed to anthropogenic impacts. In this context, the factors influencing the established trend can be seen in three aspects: (i) implementation of effective soil conservation practices; (ii) impact of demographic factors and (iii) impact of construction of dams and reservoir siltation.

Implementation of effective soil conservation practices was conducted in a planned manner in certain parts of the basin. Comprehensive scope of anti-erosion works was carried out in the South Morava River Basin in the period 1961-1988, and in the Zapadna Morava River Basin in the period 19471977. In addition to the classic forestation, the following has been introduced: application of biotechnical works, anti-erosion techniques in agricultural production and construction of various partition objects on torrential basins (Petković et al., 1995, 1996).

Individual studies in the area of the Velika Morava River Basin have indicated the role of demographic

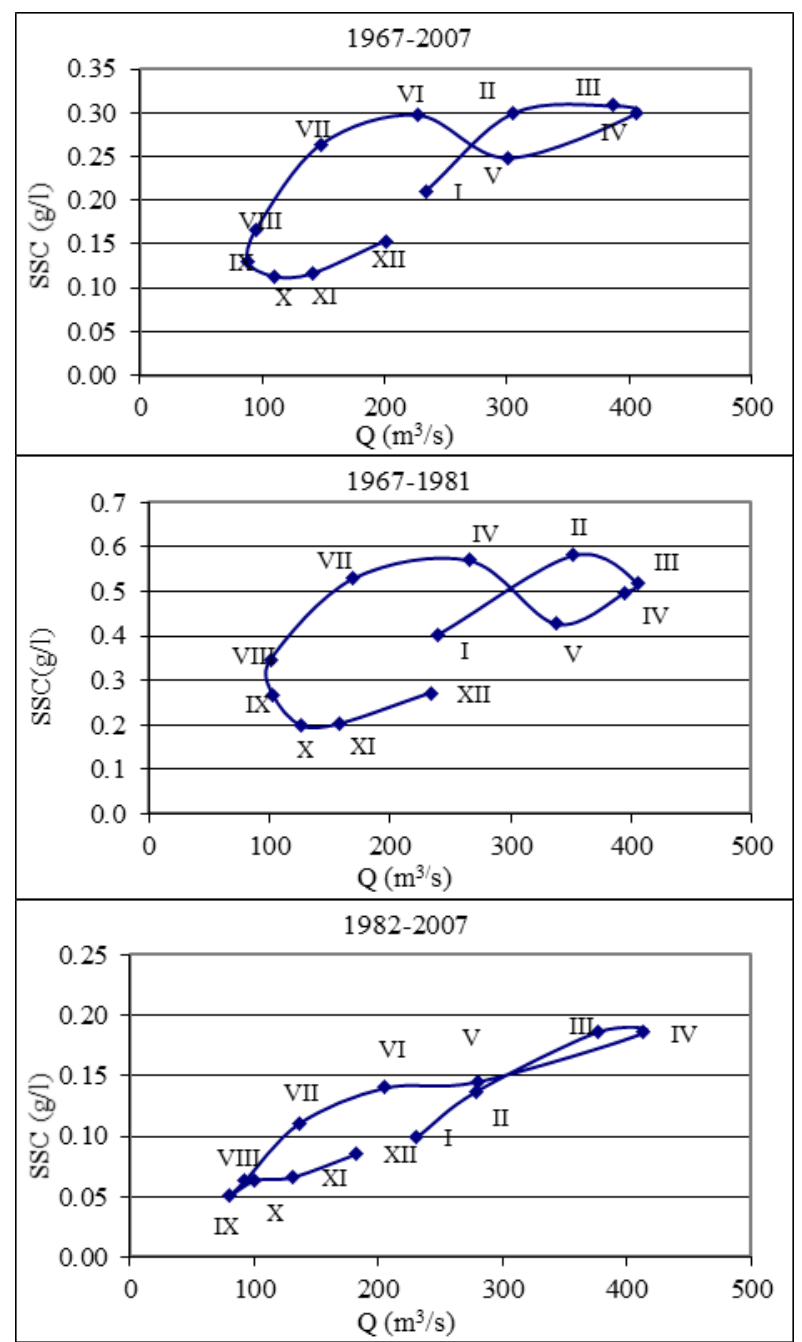

Figure 4 Hysteresis loop in the period 1967-2007, before transition year T (1967-1981) and after transition year T (1982-2007), detected by the Pettit test

component in decreasing the intensity of soil erosion, and therefore the suspended sediment load (Kostadinov et al., 2014; Mustafić, 2007; Mustafić et al., 2008). In this context, the continuing population decline in the second half of the $X X$ and very strong negative average annual rate of the first decade of the XXI century are especially distinguished (Spasovski et al., 2012), as well as, the process of demographic aging of the population, the general deruralization and depopulation in rural areas of Central Serbia (Martinović, 2012). Rural areas experienced the characteristics of rural exodus during the 1960s, culminated in the period 1971-1981, when 1.4 million people left the agricultural production (Martinović and Ratkaj, 2015). Negative 
demographic processes have continued until today. Leaving rural areas has resulted in reduction of agricultural pressure on land, which reflected on grassing of arable land and therefore the reduction in intensity of soil erosion.

Certainly one of the most important factors in decreasing the suspended sediment load is the impact of water reservoirs. Reservoir siltation is expressed to the extent that most of them was silted by $30-50 \%$ in the first twenty years of construction. The extreme example is the reservoir of the Zapadna Morava River, which lost $50 \%$ of the total volume in the first three years of operation and very quickly was completely silted (Milinčić, 2009).

\section{Conclusion}

The paper deals with interannual and intraannual dynamics of suspended sediment load of the Velika Morava River on its most downstream hydrological profile Ljubičevski most in the period 1967-2007. The following can be concluded from the above mentioned studies:

(i) On the average, the Velika Morava River gives $220.3 \mathrm{~m}^{3} / \mathrm{s}$ to the Danube, which gives the specific runoff value of $6.2 \mathrm{l} / \mathrm{s} / \mathrm{km}^{2}$. In addition, $2.57 \times 10^{6} \mathrm{t}$ of suspended sediment was transported on the average for a period of 40 years, which made the average specific sediment load of $72.4 \mathrm{t} / \mathrm{km}^{2} / \mathrm{yr}$. The results of the Mann-Kendall test showed that the average decrease of suspended sediment load was $111,094.5 \mathrm{t} / \mathrm{yr}$, or $3.15 \mathrm{t} / \mathrm{km}^{2} / \mathrm{yr}$. The results of the Pettitt test showed that the change-point year was detected in 1982. Average specific sediment load before the transition year amounted to 134.6 $\mathrm{t} / \mathrm{km}^{2} / \mathrm{yr}, 36.5 \mathrm{t} / \mathrm{km}^{2} / \mathrm{yr}$ after the transition year, i.e., it was reduced by $73 \%$. Interannual trend of decrease of suspended sediment and suspended sediment concentration was very pronounced $(\alpha=0.001)$, compared to the runoff trend which recorded no statistical significance.

(ii) Intraannual distributions of suspended sediment exhibit strong seasonal characteristics. The largest sediment load was carried out during March, April and May (nearly 50\%). Changes in the seasonal distribution of suspended sediment load showed a decreasing trend. The most obvious decreasing trend was evident during summer and winter $(\alpha=0.001)$, and the lowest in autumn $(\alpha=0.01)$. Changes on the monthly level showed negative trends without exception during all twelve months. The most prominent significant changes of suspended sediment were in July and August, and then in June and September, on the level of significance of 0.001 , and 0.01 respectively.

(iv) The ratio of discharge and suspended sediment concentration showed that the hysteresis loop was in the shape of figure eight, indicating complex conditions in the basin. Analysis of the hysteresis loop, done for the period before and after the transition year $T$, indicated some changes in the relationship between SSC and $Q$. Thus, for the maximal values of $Q$ (April), the values of SSC in the period after the transition year were 2.7 times lower than in the period before the transition year. Also, in the period after $\mathrm{T}$, the suspended sediment concentrations significantly decreased especially during February and June.

(v) The decreasing trend of suspended sediment is mostly attributable to anthropogenic impacts. The impact of humans manifested through various forms of anti-erosion soil conservation practices, negative demographic trends reflected in the depopulation of rural areas of the basin, as well as the impact of water reservoirs which largely deposited suspended sediment over time.

The obtained results have great application value. First of all, they can be involved in the adequate planning of water resources.

\section{Acknowledgements}

This paper is part of the project "The Research on Climate Change Influences on Environment: Influence Monitoring, Adaptation and Mitigation" (43007), subproject No 9 "Torrential Floods Frequency, Soil and Water Degradation as the Consequence of Global Changes", financed by the Ministry of Education and Science of the Republic of Serbia. 


\section{References}

Babić-Mladenović M. 2007. Sediment regime of the Danube River. Andrejević Foundation, 124 p.

Chakrapani GJ. 2005. Factors controlling variations in river sediment loads. Current Science 88: 569-575.

Chakrapani GJ, Subramanian V. 1990. Factors controlling sediment discharge in the Mahanadi River Basin, India. Journal of Hydrology 117(1-4): 169-185.

Cohen S, Kettener A, Syvitski J. 2014. Global suspended sediment and water discharge dynamics between 1960 and 2010: Continental trends and intra-basin sensitivity. Global and Planetary Change 115: 44-58.

Dragicević S, Filipović D, Kostadinov S, Ristić R, Novoković I, Zivković N, Andjelković G., Abolmasov B, Secerov V, Djurdjić S. 2011. Natural Hazard Assessment for Land-use Planning in Serbia. International Journal of Environmental Research 5(2): 371-380.

Ducić0 V, Radovanović M. 2005. Climate of Serbia. Institute for textbooks and teaching aids, Belgrade, 2012 p.

Gao P, Mu XM, Wang F, Li R. 2011. Changes in streamflow and sediment discharge and the response to human activities in the middle reaches of the Yellow River. Hydrol. Earth Syst. Sci. 15: 1-10.

Gao ZL, Fu YL, Li YH, Liu JX, Chen N, Zhang XP. 2012. Trends of streamflow, sediment load and their dynamic relation for the catchments in the middle reaches of the Yellow River over the past five decades. Hydrol. Earth Syst. Sci. 16: 3219-3231.

Gavrilović LJ, Milanović-Pesić A, Urosev M. 2012. A hydrological analysis of the greatest floods in Serbia in the 1960 - 2010 period. Carpathian Journal of Earth and Environmental Sciences 7(4): 107-116.

Gocić M, Trajković S. 2013. Analysis of precipitation and drought data in Serbia over the period 1980-2010, Journal of Hydrology 494: 32-42.

Hooke JM. 2006. Human impacts on fluvial systems in the Mediterranean region. Geomorphology 79:311-335.

Karmeshu N. 2012. Trend Detection in Annual Temperature \& Precipitation using the Mann Kendall Test - A Case Study to Assess Climate Change on Select States in the Northeastern United States. MSC Thesis, University of Pennsylvania.

Kostadinov S, Zlatić M, Dragićević S, Novković I, Kosanin O, Borisavljević A, Lakićević M, Mladjan D. 2014. Anthropogenic Influence on Erosion Intensity Changes in the Rasina River Watershed - Central Serbia. Fresenius Environmental Bulletin 23(1A): 254-263.

Kutiel H, Luković J, Burić D. 2015. Spatial and temporal variability of rain-spells characteristics an Serbia and Montenegro. International Journal of Climatology 35: 1611-1624.
Martinović M. 2012. Types of population dynamics in settlements of Zaplanje area. Bulletin of the Serbian Geographical Society 92(2): 133-152.

Martinović M, Ratkaj I. 2015. Sustainable Rural Development in Serbia: Towards a Quantitative Typology of Rural Areas. Carpathian Journal Of Earth And Environmental Sciences 10(3): 37-48.

Meysam S, Akhond-Ali AM, Adib A, Daneshkhah A. 2012. Trend and change-point detection for the annual stream-flow series of the Karun River at the Ahvaz hydrometric station. African Journal of Agricultural Research 7: 4540-4552.

Milincić M. 2009. Spring Zones of Surface Water in Serbia - Ecological Limits and Revitalization of Settlements. University of Belgrade-Faculty of Geography, Belgrade, $281 \mathrm{p}$.

Mitchell JM, Dzezerdzeeskii B, Flohn H, Hofmeyer WL, Lamb HH, Rao KN, Wallen CC. 1996. Climatic change. WMO Technical Note 79, WMO 195, 79 p.

Mustafić, S. 2007. Certain aspects of anthropogenic influence on the intensity of the erosive process in Temstica river basin. Bulletin of the Serbian Geographical Society 87(1): 23-30.

Mustafić S, Kostainov S, Manojlović P. 2008. Risk of artificial lake 'Zavoj' to processes of erosion: Methodological, knowing and protecting aspect. Bulletin of the Serbian Geographical Society 88(1): 29-42.

Mustafić S, Manojlović P, Nikolić M, Dobrosavljević T. 2014. Trend of suspended sediment load in the Velika Morava river in the period 1967-2007. Bulletin of the Serbian Geographical Society XCIV(4): 35-48.

Mustafić S, Manojlović P, Milosević M. 2013. Extreme Erosion Rates in the Nisava River Basin (Eastern Serbia) in 2010. In: Loczy D (ed.), 'Geomorphological Impacts off Ekstreme Weather. Case Studies from Central and Eastern Europe. Springer, 171-187.

Nu-Fang F, Zhi-Hua S, Lu L, Cheng J. 2011. Rainfall, runoff, and suspended sediment delivery relationships in a small agricultural watershed of the Three Gorges area, China. Geomorphology 135: 158-166.

Ocokljić M. 1987. Altitude zoning of water in Velikamorava basin and some aspects of their protection. Serbian Geographical Society, Belgrade 64: 1-92.

Ocokljić M. 1994. Cyclicality of drought and aquatic period in Serbia. Serbian Academy of Sciences and Arts - Geographical Institute "Jovan Cvijić" 41: 1-110.

Petrović A, Kostadinov S, Dragićević S. 2014. The Inventory and Characterization of Torrential Flood Phenomenon in Serbia", Pol. J. Environ. Stud. 23(3): 823-830.

Petković S, Dragović N, Marković S. 1999. Erosion and sedimentation problems in Serbia. Hidrological 
Sciences-Journal-des Sciences Hydrologiques, 44(1): 63-77.

Petković S, Popović M, Kostadinov S, Potić O, Zlatić M, Dragović N, Marković S, Velojić M. 1995. Sediment Management in the South Morava River Basin. University of Belgrade-Faculty of Foresty, $215 \mathrm{p}$.

Petković S, Kostadinov S, Petković S, Zlatić M, Đeković V, Dragović N, Marković S. 1996. Sediment Management in the West Morava River Basin. University of Belgrade-Faculty of Foresty, $158 \mathrm{p}$.

Pettitt AN 1979. A non-parametric approach to the change-point problem. Applied statistics 28: 126-135

Ristić R, Kostadinov S, Abolmasov B, Dragićević S, Trivan G, Radić B, Trifunović M, Radosavljević Z. 2012. Torrential floods and town and country planning in Serbia. Natural Hazards and Earth System Sciences 12: 23-35.

Salarijazi M, Akhond-Ali A, Daneshkhah A. 2012. Trend and change-point detection for the annual streamflow series of the Karun River at the Ahvaz hydrometric station. African Jounal of Agricultural Research, 7: 4540-4552.

Seeger M, Errea MP, Begueria S, Arnaez J, Marti C, GarciaRuiz JM. 2004. Catchment soil moisture and rainfall characteristics as determinant factors for discharge/suspended sediment hysteretic loops in a small headwater catchment in the Spanish Pyrenees. ,Journal of Hydrology 288: 299-311.

Soler M, Latron J, Gallart F. 2008. Relationships between suspended sediment concentrations and discharge in two small research basins in a mountainous Mediterranean area (Vellcebre, Eastern Pyrenees). Geomorphology 98: 143-152.

Spasovski M, Šantić D, Radovanović O. 2012. Historical stages in transition of natural replacement of the Serbian population. Bulletin of the Serbian Geographical Society, XCII(2): 23-60.

Tosić I, Unkasević M. 2014. Analysis of wet and dry periods in Serbia. International Journal of Climatology 34: 1357-1368.

Walling DE. 2006. Human impact on land-ocean sediment transfer by the world's rivers. Geomorphology 79: 192-216.

Walling DE, Fang D. 2003. Recent trends in the suspended sediment loads of the world's rivers. Global and Planetary Change 39: 111- 126.

Williams GP. 1989. Sediment concentration versus water discharge during single hydrologic events in rivers. Journal of Hydrology 111: 89-106.

Yue S, Pilon P, Phinney B, Cavadias G. 2002. The influence of autocorrelation on the ability to detect trend in hydrological series. Hydrol. Process 16: 1807-1829.

Yue S, Pilon P, Phinney B. 2003. Canadian stream-flow trend detection: impacts of serial and cross-correlation. Hydrological Sciences Journal 48(1): 51-63.

Yue S, Pilon P. 2004. A comparison of the power of the $t$ test, Mann-Kendall and bootstrap tests for trend detection. Hydrological Sciences Journal 49(1): 21-37. 